\title{
Which Firms Get Punished for Unethical Behavior? Explaining Variation in Stock Market Reactions to Corporate Misconduct
}

\author{
Edward J. Carberry \\ University of Massachusetts Boston \\ Peter-Jan Engelen \\ Utrecht University \\ University of Antwerp \\ Marc Van Essen \\ University of South Carolina \\ emlyon business school
}

\begin{abstract}
Although there is ample evidence that stock markets react negatively to unethical corporate behavior, our understanding of the mechanisms that shape variation in these reactions across different incidents of misconduct remains underdeveloped. We propose and test a framework for explaining this variation by focusing on the role of the media in disseminating initial information about misconduct. We argue that the signaling effects of this information are important for investors because corporations have strong incentives to limit the information they disclose about misconduct. More specifically, we hypothesize that investors are more likely to react negatively when the media presents clear and credible information that misconduct occurred, that the firm was responsible for it, and that the misconduct was the result of deeper organizational problems. We also predict that information which signals that a firm has restorative capacity tempers investor reactions when the media places blame for misconduct on the corporation rather than specific individuals. We test our hypotheses in a unique sample of 345 acts of corporate misconduct in five European countries. Our findings provide broad support for our hypotheses, and we discuss implications for research on corporate misconduct and the role of non-state actors in regulating unethical corporate behavior.
\end{abstract}

KEY WORDS: corporate misconduct, corporate scandals, media, stock market reactions, event studies

$\mathrm{O}$ n September 18, 2015, the United States Environmental Protection Agency announced that Volkswagen (VW), the German car manufacturer, violated the Clean Air Act by installing software in over half a million cars designed to cheat on emissions tests. The announcement triggered extensive media coverage, which revealed that the software had been installed in over 11 million vehicles across the 
globe. VW quickly came under heavy criticism by a number of different stakeholders and the general public, CEO Martin Winterkorn resigned, and German regulators began their own investigations. A week after the initial announcement, the price of VW stock had plummeted by $50 \%$ (La Monica, 2015). Such a decline after the exposure of corporate misconduct is not surprising: not only will the misconduct impose direct costs on VW in the form of legal fees and recalls, but it will likely alter how consumers, suppliers, and other stakeholders view the company in the future. In April 2014, however, the US Department of Justice filed a lawsuit against another auto manufacturer, General Motors (GM), over faulty ignition switches linked to 124 deaths (Luckerson, 2015). GM's stock price dropped by only $1.8 \%$ in the subsequent week (Fukushima, 2014).

What explains the dramatic difference in how investors initially responded to these two seemingly similar acts of misconduct? Both firms are large, well-known auto manufacturers, and in both examples, executives appeared to have willfully engaged in unethical behavior. In VW's case, they appear to have knowingly evaded environmental regulations and defrauded consumers, while at GM, executives knowingly defrauded customers because they knew about the deadly part for over a decade but did not fix it (Ivory, 2014). Both acts generated and will continue to generate costs related to legal penalties, product recalls, and reputational damage. Why did the stock market initially react to the VW scandal so severely but not to GM's, even though GM's faulty ignition switches killed over 100 people? Although research in a number of disciplines, including business ethics (Frooman, 1997), finance (Karpoff, Lee, \& Martin, 2008), law (Alexander, 1999), and management (Janney \& Gove, 2011), has provided empirical evidence that investors react negatively to corporate misconduct, we still lack an understanding of the mechanisms shaping variation in investor reactions across different instances of misconduct. We can easily predict that investors will react negatively to an oil spill on the scale of BP's in the Gulf of Mexico in 2010, but what about cases that are not as clear-cut or high profile? Do investors always react negatively to corporate misconduct and how do we explain why "punishment [is] used selectively against some responsible organizations but not others" (Greve, Palmer, \& Pozner, 2010: 85)?

Gaining deeper insight into these questions has become more critical with the acceleration of globalization and the related spread of shareholder value ideology (Fiss \& Zajac, 2004; Stout, 2012), both of which have weakened the power of national governments to regulate corporate behavior (Scherer, Palazzo, \& Baumann, 2006; Scherer, Palazzo, \& Matten, 2009) and provided non-state actors, such as shareholders and the media, with more influence in both promoting ethical business behavior (Flammer, 2012; Grafström \& Windell, 2011) and monitoring unethical behavior (Breit, 2009; Dai, Parwada, \& Zhang, 2015). To the extent that firms experience a decline in their share prices because of misconduct, shareholders may function as effective deterrents of unethical behavior. In addition, negative investor reactions can increase scrutiny of the offending corporation and pave the way for broader stigmatization processes by a larger number of stakeholders that can lead to more severe consequences for the firm (Devers, Dewett, Mishina, \& Belsito, 2009; Dorobantu, Henisz, \& Nartey, 2017). To the extent that the market is inefficient in punishing 
misconduct (Wesley \& Ndofor, 2015), however, new regulatory and enforcement mechanisms may be required.

In this article, we develop and test a framework for explaining variation in investor reactions to corporate misconduct by focusing on how the media initially expose misconduct. Although the efficient market hypothesis on which most existing research rests assumes that stock prices change when new information becomes available to investors, the relationship between the types of information available about misconduct and investor reactions to it has seldom been the focus of theoretical or empirical attention. Our approach rests on the core assumption that corporations under scrutiny for misconduct face strong motivation to limit the amount of information they disclose in order to mitigate the potential damage and protect their reputations (Doh, Howton, Howton, \& Siegel, 2009; Suchman, 1995). In the face of this information asymmetry, we argue that investor assessments of and reactions to misconduct will be importantly shaped by the signaling effects of information available in the media. Research in management (Bednar, 2012; Pollock \& Rindova, 2003), finance (Core, Guay, \& Larcker, 2008; Tetlock, 2007), and accounting (Dai et al., 2015; Miller, 2006), for example, has demonstrated that the media play an important governance role as information intermediaries (Bushee, Core, Guay, \& Hamm, 2010; Deephouse \& Heugens, 2008) by reducing information asymmetry to influence investor behavior (Aguilera, Desender, Bednar, \& Lee, 2015). Since corporate misconduct is fundamentally socially constructed (Greve et al., 2010), the media will play an important role in shaping the social evaluations of corporate behavior that can potentially be categorized as misconduct (Goodstein, Butterfield, Pfarrer, \& Wicks, 2014).

To hypothesize the effects of information reported by the media on investor reactions, we draw upon key insights from broader sociocognitive approaches to market behavior developed in the management literature (Lange \& Washburn, 2012), which has examined how market actors assess organizations and organizational actions by using signals and cues (Bergh \& Gibbons, 2011; Janney \& Gove, 2011; Mishina, Block, \& Mannor, 2012; Park \& Patel, 2015). More specifically, we argue that investors will be more likely to react negatively to misconduct when the media focuses more attention on it, and presents clear and credible information that misconduct occurred, that the firm was responsible for it, and that it was the result of deeper organizational problems. We focus on the initial media coverage because it broadcasts information about misconduct widely for the first time and sets initial expectations. When the media provides visible, clear, and credible signals in this initial coverage, we predict that a larger percentage of investors will pay attention to the misconduct and agree in their interpretations of it. The overall effect of this agreement will be reflected in negative abnormal stock returns for the firm. In contrast, when the media provides ambiguous signals, investors will be less able to interpret the information, leading to more heterogeneity in responses that likely diffuses the overall reaction of the stock market.

In addition to our contribution to the literature on investor reactions to unethical corporate behavior, our application of recent insights about the media from the management, accounting, and finance literatures highlights the potential of forging deeper connections between specific strands of these literatures and business ethics scholarship. Although the latter has examined how the media can motivate firms to 
engage in ethical behavior by functioning as agenda-setters for CSR (Grafström \& Windell, 2011; Lee \& Riffe, 2017), covering firms positively (Bansal \& Clelland, 2004; Dickson \& Eckman, 2008), and monitoring firms when there are high-levels of press freedom (El Ghoul, Guedhami, Nash, \& Patel, 2016), it has focused less on how the media can deter unethical behavior by reducing information asymmetry and focusing the attention of stakeholders. Moreover, although business ethics scholarship has devoted increased attention to the causes of corporate misconduct (Shadnam \& Lawrence, 2011) and the ways in which firms can repair trust, rehabilitate, and reintegrate following misconduct (Bertels, Cody, \& Pek, 2015; Brown, Buchholtz, \& Dunn, 2016; Gillespie, Dietz, \& Lockey, 2014; Goodstein \& Butterfield, 2010), it has paid less attention to the role of the media in shaping how corporate misconduct is constructed and how stakeholders react to it. Indeed, the role of the media in "shaping stakeholders" perceptions of a transgression... remains fertile ground for theoretical and empirical developments" (Goodstein et al., 2014: 331). Understanding the role of the media in shaping investor reactions to misconduct is particularly important with recent evidence that markets may not necessarily punish unethical behavior efficiently (Wesley \& Ndofor, 2015).

We test our theoretical claims by using event study and regression methodologies to examine negative abnormal stock returns in a unique sample of 345 acts of corporate misconduct in the United Kingdom, France, Germany, The Netherlands, and Belgium from 1995 to 2005 . Not only does our sample provide a logical setting for testing the general applicability of our framework across multiple countries, but also across multiple types of misconduct, including accounting fraud, tax fraud, insider trading, corruption and bribery, monopolistic pricing, employee discrimination, environmental violations, and human rights violations. Previous research has primarily focused on one or two different types of misconduct, making it difficult to compare findings across different samples. Our findings support our core claims that investors react more negatively to misconduct when the media provide clearer and more credible information that misconduct has occurred, that the firm is responsible for it, and that the misconduct was the result of deeper organizational problems. We also find that information that signals that the firm has restorative capacity tempers investors reactions when the media assigns blame for the misconduct to the corporation rather than specific individuals. In addition, our findings provide the first evidence from a large cross-national sample of misconduct events in Europe. If, as some have argued, the regulatory system relating to misconduct is weaker in Europe (Enriques \& Volpin, 2007), understanding the deterrent effects of stock markets and the media in this context is crucial.

\section{CORPORATE MISCONDUCT, INVESTORS, AND INFORMATION ASYMMETRY}

Most research examining investor reactions to misconduct rests on the efficient markets hypothesis, which assumes that investors make rational decisions based on available information about future cash flows (Barberis \& Thaler, 2003). In other words, "the theoretical value of any firm is the present value of its expected cash 
flows discounted at a risk-adjusted rate of return" (Davidson \& Worrel, 1988: 195), and stock prices change when new information becomes available to investors about the firm's future profitability. Therefore, if the stock market reacts negatively to news of misconduct, the stock price decline is a direct measure of investors' expectations about the impact of the total net cost to the firm based on available information (Engelen \& van Essen, 2011).

What are the costs of misconduct to corporations? The most obvious are direct, legal costs associated with paying fines and settling lawsuits (Muoghalu, Robison, \& Glascock, 1990). In addition, acts of misconduct can inflict costs arising from two others sources (Karpoff \& Lott, 1993). The first is the cost of replacing employees and implementing new monitoring practices to ensure that misconduct does not recur (Alexander, 1999; Karpoff et al., 2008). The second are reputational penalties, which represent the most significant proportion of negative market reactions to misconduct (Karpoff, 2012). Reputational penalties emerge when direct exchange partners "change the terms by which they are willing to do business with the firm ... [because] they believe that the chance of being harmed by a firm's opportunistic behavior increases" (Karpoff, 2012: 362). For example, when lenders receive news about accounting fraud, they will be less certain about the firm's ability to pay back existing loans and may seek to renegotiate interest rates, while future lenders may impose higher interest rates. Such punitive measures can also be taken by other stakeholders who are engaged in direct exchange with the deviant firm, including suppliers, employees, and consumers (Alexander, 1999). Therefore, to the extent that investors expect or observe such actions by other stakeholders, the stock price of a deviant firm will decline as investors adjust their expectations about the firm's future profitability (Engelen \& van Essen, 2011).

Although investor reactions to misconduct are based on available information about it, the relationship between these reactions and the types of information available has seldom been theorized or analyzed empirically. Beyond providing evidence that investors react negatively to misconduct, the primary insight of the existing literature is that investors react more negatively to misconduct that affects stakeholders with whom the firm has direct exchange relationships, such as employees and consumers (King \& Soule, 2007), than to misconduct that affects stakeholders with whom the firm does not have such relationships, such as the natural environment (Karpoff, 2012). Although some studies have gone beyond this to examine how market reactions vary by stages of an investigation (Christensen, Paik, \& Williams, 2010; Muoghalu et al., 1990) and the ultimate severity of misconduct (Hirsh \& Cha, 2015), our understanding of the connections between investor reactions and the information available about misconduct remains underdeveloped.

Gaining a deeper understanding of these connections is particularly important because corporations facing scrutiny about misconduct have strong incentives to limit the amount of information they disclose (Doh et al., 2009). By limiting disclosure, corporate managers can exert control over what investors and other stakeholders know about the alleged misconduct, protect their firm's reputation in the short term by not admitting any wrongdoing, and potentially limit the damage 
(Ashforth \& Gibbs, 1990; Suchman, 1995; Zavyalova, Pfarrer, Reger, \& Shapiro, 2012). Under these conditions of information asymmetry, the media will play a critical role in exposing the misconduct to investors and shaping their expectations about reputational damage. A rapidly growing literature in management, for example, has demonstrated that the media disseminate a range of information about corporations, and influence how different types of audiences perceive and make sense of corporate behavior (Bednar, Boivie, \& Prince, 2013; Deephouse \& Heugens, 2008; Waldron, Navis, \& Fisher, 2013). Similarly, work in finance and accounting has demonstrated the critical role that the media can play in corporate governance by reducing information asymmetry (Fang \& Peress, 2009) and functioning as watchdogs who monitor top managers (Miller, 2006).

Generally, the media influence investor behavior by exposing corporate actions and framing them in specific ways (McCombs \& Shaw, 1972; Pollock \& Rindova, 2003). In the case of misconduct, we propose that two important characteristics of the initial media coverage influence investor reactions: the volume of media coverage, which can focus the attention of investors, and the content of media coverage, which can enhance the clarity and credibility of the claims about the misconduct and help investors assess the potential depth of organizational problems. We now turn to motivating our hypotheses about the volume and content of coverage.

\section{Focusing Attention on Misconduct}

Research in behavioral finance (Barberis \& Thaler, 2003; Hirshleifer \& Teoh, 2003) with its connections to more established work in cognitive psychology (Kahneman \& Tversky, 1979; March, 1978), emphasizes that investors, like all individuals, face constraints on their ability to access and process information. In the case of misconduct, these limits can be exacerbated by additional information asymmetry created by the firm under scrutiny. Investor reactions to misconduct, therefore, will first depend on whether investors notice it (Barnett, 2014), i.e., whether it falls "within their strategic field of vision and overcome other stimuli" (Bundy et al., 2013: 359).

Since the media play an agenda-setting role by focusing the public's attention on specific issues (Carroll \& McCombs, 2003; McCombs, 2005), the volume of coverage they devote to an act of misconduct can make it more difficult for investors to ignore it. Indeed, prior research has found that the volume of media coverage has an important effect on investor reactions to IPOs (Pollock \& Rindova, 2003) and earnings announcements (Bushee et al., 2010). In addition, a large literature in management and organizational theory has demonstrated the critical role of the media in exposing corporate misconduct (Desai, 2011; Greve et al., 2010; Jonsson \& Buhr, 2011). As the volume of media coverage of misconduct increases, therefore, it will focus the attention of more investors and stakeholders, making it more difficult for them to ignore it, and raise their expectations about the likelihood that stakeholders will notice it and impose reputational penalties. Moreover, the firm will become more vulnerable to the dynamics of stigmatization that can damage firms more seriously (Carberry \& King, 2012; Desai, 2011; Devers et al., 2009), and invite broader investor and stakeholder attention. We therefore predict that as 
media coverage of an act of misconduct increases, investor attention will become more focused on the act. Therefore:

Hypothesis 1: Investors react more negatively to misconduct that receives more media coverage.

\section{Enhancing the Clarity and Credibility of Claims about Misconduct}

Although the volume of media coverage will likely focus investor attention, the media can also influence investor interpretations and reactions by how they report the misconduct. Corporate behavior that can be classified as misconduct only becomes misconduct through a process of social construction (Palmer, 2012) in which observers assess and agree about the behavior under scrutiny. More specifically, corporate behavior will not be considered misconduct "unless judgments ... are made in comparison to laws that have been written, ethical principles that have been promulgated, [or] norms of social responsibility that have been elaborated" (Greve et al., 2010: 78). The media help to construct specific corporate behaviors as misconduct (Breit, 2009) through the types of information they include in their coverage and the way in which they frame the information (Ahmad, Han, Hutson, Kearney, \& Liu, 2016; Pollock \& Rindova, 2003; Rhee \& Fiss, 2014).

To theorize which information reported by the media will be important, we draw upon signaling theory, which was originally developed by Spence (1973) to explain how job seekers send signals to potential employers regarding their employability within labor markets characterized by information asymmetry. Management scholars have more recently applied signaling theory to explain variation in investor behavior in a number of different contexts, including stock option backdating (Janney \& Gove, 2011), the hiring of consultants (Bergh \& Gibbons, 2011), CEO certifications of financial statements (Zhang \& Wiersema, 2009), and the valuation of IPOs (Certo, 2003; Park \& Patel, 2015). This work has relaxed one of the original assumptions of signaling theory that signals are sent intentionally by one market actor to others. As Bergh and Gibbons (2011: 546) have shown, under conditions of information asymmetry, even if signals are not sent intentionally by a firm, investors will still look to "observable and alterable characteristics" to make sense of investment opportunities.

Signaling theory focuses attention on how observers use specific pieces of information to develop broader assessments of organizations and organizational actions (Spence, 2002). In the case of misconduct, since firms are motivated to maintain information asymmetry, media coverage will be one of the primary transmitters of signals to investors. When the media provide information that allows investors to more clearly interpret the behavior as misconduct, investors will view the claims as more credible, making it less likely that they will ignore the claims and more likely that they will expect stakeholders to inflict reputational damage. This will reduce variation in investor interpretations and responses, increasing the percentage of investors who will sell their shares, which will be reflected in a decrease in the stock price, i.e., negative abnormal returns. ${ }^{1}$ In contrast, "when signal quality is difficult to judge, investors treat signals as ambiguous" (Epstein \& Schneider, 2008: 197). In the case of misconduct, ambiguous signals will mean that investors will be less able to 
interpret the information and more likely to ignore it, leading to more heterogeneity in responses that diffuse the overall reaction of the stock market.

The ultimate legitimacy of claims about misconduct, therefore, depend on observers having clear and credible information that it was misconduct that occurred and that the company is responsible for it. We propose that three specific types of information will function as signals to facilitate these judgements.

First, for investors and other stakeholders to consider and label corporate behavior as misconduct, it must be understandable within their existing cultural schema and accepted norms of ethical corporate behavior. Although most firms now operate globally and can engage in misconduct in different countries, laws, ethical principles, and norms are importantly constructed at the national level. We therefore argue that when the media reports misconduct as occurring within the country in which investors are located, this will provide a clearer and more credible signal to investors that misconduct has occurred. This claim is supported by broader work in finance that has demonstrated that investors exhibit a "home country" bias, i.e., they tend to invest in stocks of firms that are headquartered in their own countries (Barberis \& Thaler, 2003; Huberman, 2001). One of the primary explanations for the home country bias is that domestic firms are more familiar to investors (Barberis \& Thaler, 2003). An important corollary is that not only are the portfolios of most investors concentrated in firms in their own countries, but the distribution of ownership of individual firms is concentrated among domestic investors, as is the case in Western Europe (Huizinga \& Nicodème, 2006). As the global reach of many firms has increased, however, acts of misconduct occur all over the world, with national culture and social institutions influencing the likelihood of which types of misconduct will occur (Bame-Aldred, Cullen, Martin, \& Parboteeah, 2013; Martin, Cullen, Johnson, \& Parboteeah, 2007). Since most of a firm's investors will be located in the country where a firm is headquartered, however, acts of misconduct that occur in this country will be more legally, ethically, and normatively interpretable for a larger proportion of investors than acts that occur in other countries. When the media reports that an act has occurred within the home country of the firm and investors, therefore, this will enhance the overall clarity and credibility of the signal for a larger proportion of investors. We therefore predict:

Hypothesis 2: Investors react more negatively to acts of corporate misconduct that occur in the country where a firm is headquartered than to acts that occur outside of the country in which a firm is headquartered.

Simply because the alleged behavior is more understandable within the institutional and cultural environment of investors, however, does not necessarily mean that there will be agreement that misconduct actually occurred and that the firm is responsible for it. Two other specific types of information, however, can function as signals to facilitate these judgements. For example, although observers will judge misconduct in comparison to laws, ethics, and norms, the clearest way in which misconduct is defined as such is by regulatory officials with the authority of the state. These are the key "line drawers, monitors, and enforcers" (Greve et al., 2010), 
who determine which "behaviors are wrongful" (Palmer, 2012: 78). Therefore, if the media reports in its initial coverage that the act is under investigation, this will enhance the clarity and credibility of the signal that it was misconduct that occurred and that the firm is responsible for it (Lange \& Washburn, 2012). Paruchuri and Misangyi (2015), for example, found that government investigations of misconduct mitigated negative spillover effects to innocent industry peers because investigations increased investor perceptions of the perpetrating firm's responsibility.

The media can cover acts of misconduct at different stages of the social construction process. The first stage is the rumor stage. The next stage is the initiation of a formal investigation by a regulatory agency, followed by the completion of the investigation, which can end in a number of ways, including exoneration, the imposition of fines, or the filing of additional legal charges that lead to proceedings by a court or other adjudicatory body. Although some studies have found that investor reactions to misconduct may vary across different stages of social control (Christensen et al., 2010; Karpoff \& Lott, 1993; Muoghalu et al., 1990), they have focused primarily on investor reactions to a single act of misconduct at different stages, rather than how reactions to different acts that are exposed at different stages may vary. If an act of misconduct is under formal investigation at the time it is exposed, investors will see the claims of responsibility as more credible than an act exposed in the rumor phase. In later stages, such as the end of an investigation or the court phase, investors are not likely to be receiving a great deal of new information (Agguzoni, Langus, \& Motta, 2013; Muoghalu et al., 1990). This leads to our next hypothesis:

Hypothesis 3: Investors react more negatively to acts of corporate misconduct that are exposed during a formal stage of investigation than those exposed during any other stage of the social construction process.

Finally, attribution theory, which was developed in social psychology (Berscheid, Graziano, Monson, \& Dermer, 1976) and has recently become more broadly used in the management literature (Lange \& Washburn, 2012), allows us to identify another type of information that will clarify that misconduct occurred and that the firm is responsible for it. More specifically, one of the most important factors that facilitates blame attribution is a clear link between an act and undesirable effects (Hamilton, 1980). Although perceptions of undesirable effects depend in part on the "magnitude of consequences" of the misconduct (Brown et al., 2016), there is often uncertainty about severity when misconduct is first reported in the media. Information about the potential or actual consequences of misconduct is not always reported, and when it is, it is usually in the form of estimates because the final quantifiable outcomes are often not known until long after the misconduct has been initially exposed (Hirsh \& Cha, 2015). However, we argue that any concrete information about the potential, estimated, or initial impacts of misconduct that the media report will facilitate blame attribution. Such information might include the estimated value of misstated earnings, the number of shares traded on insider information, or the amount of an 
alleged bribe. In addition, this information will enhance the clarity and credibility of claims that it was misconduct that occurred because the consequences of the behavior will be more real and concrete to investors. Hence:

Hypothesis 4: Investors react more negatively to acts of misconduct when the media discloses any estimated or actual impacts of the misconduct.

\section{Focus of Blame and Restorative Capacity}

While certain information reported in the media will likely enhance the clarity and credibility of the claims about misconduct, investor expectations about whether a firm will incur reputational penalties will also be influenced by their assessments about the likelihood that the firm will repeat the behavior in the future (Connelly, Ketchen, Gangloff, \& Shook, 2016; Karpoff, 2012). If the misconduct appears to be an aberration and easily solved, investors will be less likely to expect that stakeholders will impose reputational costs. If specific individuals are blamed, for example, the firm can more easily address the problems (or at least give the appearance of doing so) by firing these employees (Devers et al., 2009). Indeed, firms will often assign blame to specific people to divert attention away from assessments that implicate the entire firm (Paruchuri \& Misangyi, 2015), and firms will often fire CEOs after misconduct has been exposed (Connelly et al., 2016). If the media attributes blame for the misconduct to one person or a small group of people, therefore, investors will be more likely to see them as "bad apples" (Felps, Mitchell, \& Byington, 2006) and view the misconduct as an isolated incident that can be easily rectified (Janney \& Gove, 2011). If so, investors will be less likely to expect that stakeholders will inflict reputational damage by altering the terms of or withdrawing from exchange with the firm. An exception, however, is that if top executives are implicated, this suggests deeper organizational problems than if lower level employees are implicated (Brown \& Treviño, 2006).

If an act of misconduct is blamed on the corporation in general, however, this signals that the act more likely stems from "moral collapse" (Shadnam \& Lawrence, 2011), i.e., enduring, systemic problems relating to organizational structures (Palmer \& Yenkey, 2015), or an ethical climate and culture (Greve et al., 2010; Martin \& Cullen, 2006; Treviño, Weaver, \& Reynolds, 2006) that promotes misconduct and normalizes it (Martin, Johnson, \& Cullen, 2009; Vaughan, 1997). As Palmer (2012: 37) observes: "collective wrongdoing wreaks more damage on organizations and societies than individual wrongdoing, because the more people involved in a wrongful course of action, the more it can accomplish." We therefore predict that if media coverage assigns blame to the corporation, this signals that the misconduct was the result of systemic organizational problems, as opposed to a small number of individuals who deviated from otherwise sound internal policies and procedure, and investors will be more likely to expect reputational damage. Hence:

Hypothesis 5: Investors react more negatively to acts of corporate misconduct that are blamed on the corporation itself than acts blamed on individual employees. 
Finally, our framework has focused on theorizing the effects of information reported in the media about acts of misconduct. Since this information will be new to stock market participants, it is likely to be reflected in market reactions. Although firms that engage in misconduct will themselves vary along a number of dimensions, since firm-level information will not be new to investors, the efficient market hypothesis would not predict that this information would influence investor behavior. However, we argue that a firm's restorative capacity will moderate the predicted relationship between the focus of blame and investor reactions to misconduct. We define restorative capacity as a firm's capacity to engage in actions to restore its legitimacy (Pfarrer, Decelles, Smith, \& Taylor, 2008) and repair trust (Gillespie \& Dietz, 2009) with internal and external stakeholders following misconduct. As described in the frameworks developed by Pfarrer et al. (2008) and Gillespie and Dietz (2009), effectively restoring legitimacy and repairing trust require both verbal responses through which a firm acknowledges the wrongdoing, accepts responsibility, and offers appropriate explanations, and substantive actions through which the firm makes good-faith efforts to investigate and report the causes of the misconduct, and make changes to the organizational practices, policies, incentives, and cultural elements that contributed to the misconduct. Legitimacy restoration and trust repair also require outreach and dialogue with external stakeholders to rebuild trust and restore relationships. The actions needed to effectively restore legitimacy, repair trust, and reintegrate an organization with its stakeholders, therefore, are extensive and involve a number of different organizational systems (Gillespie \& Dietz, 2009), and thus require significant resources, managerial skills, and careful planning (Bertels et al., 2015; Gillespie et al., 2014). This suggests that a firm's restorative capacity will importantly depend on committed leaders who understand the challenges and complexity of restoration and reintegration, and are willing to devote the required resources and time to it.

Investors will be most concerned about restorative capacity when the corporation itself is blamed for the misconduct, which signals that the misconduct was the result of more systemic organizational problems that are more difficult to address. When the corporation is blamed, but investors believe that a firm has more significant restorative capacity, they will be more likely to believe that a firm will be able to address the underlying problems and less likely to expect the firm to incur reputational penalites. Although corporations will sometimes demonstrate their restorative capacity by taking swift action and providing detailed plans for addressing misconduct when it is exposed (Suchman, 1995), such action and plans often only emerge (and restorative capacity revealed) over time. Investors, in other words, are "generally aware that a failure has occurred before they encounter or have to interpret a firm's signals aimed at restoring investor confidence" (Connelly et al., 2016: 2138).

Investors might, however, form initial assessments of restorative capacity based on information that indicates that the leadership of the firm has the commitment, ability, and resources to address the causes of the misconduct. One indicator of restorative capacity is whether the firm has strong governance mechanisms in place, which can help to focus corporate managers on the challenging work of restoring legitimacy and repairing trust. Since the long-term benefits of this work may not 
be obvious, however, corporate managers may prefer to engage in the least costly and quickest courses of action, which may not be the most effective (Gillespie \& Dietz, 2009). For example, defensive actions that deny or downplay misconduct, or that decouple espoused actions from their implementation, likely mitigate the effectiveness of efforts to restore legitimacy (Gillespie et al., 2014; Goodstein et al., 2014). In addition, it may be difficult for potentially complicit managers to adopt the type of "open and objective approach recommended for reintegration" (Gillespie et al., 2014: 397). Strong governance mechanisms, however, can help to ensure that the firm engages in the necessary restorative actions for the long-term benefit of the firm. Independent board members, for example, provide more objective oversight of corporate managers because they are not employees of the firm and do not have direct exchange relationships with the firm (Paruchuri \& Misangyi, 2015). In the case of misconduct, independent directors will play an essential role in overseeing restorative and remedial actions, such as the implementation of new monitoring and control systems (Palmer, 2012). The independence of the board, therefore, will be an important indicator of a firm's restorative capacity when the corporation is blamed for misconduct. We therefore predict:

Hypothesis 6: The negative relationship between the corporation being blamed for misconduct and investor reactions will be positively moderated by the percentage of independent directors.

\section{DATA AND METHODS}

To test our hypotheses, we used multivariate OLS regression with cumulative abnormal returns as the dependent variable (Paruchuri \& Misangyi, 2015). The dataset was constructed by using electronic, full-text newspaper databases to search for all acts of corporate misconduct reported in the press in five European countries between 1995 to 2005, including the United Kingdom, Germany, France, the Netherlands, and Belgium. We identified all reported acts of misconduct by using the following keywords (and their equivalents in French, German, and Dutch): financial misrepresentation, accounting fraud, tax fraud, fraud, forgery, swindling, corruption, bribery, insider trading, insider dealing, market abuse, cartel, price fixing, anti-trust, monopoly, human rights violation, discrimination, environmental violations, environmental breach, environmental damage, and pollution.

We identified 471 distinct corporate misconduct events. In order to eliminate the impact of confounding events, we dropped those events that occurred on the same day the firm made other announcements or that involved multiple types of misconduct. Our initial sample was further reduced for several other reasons. First, ten events were dropped due to missing or incomplete stock price data in Thomson Reuters Datastream. Second, we dropped 28 events due to overlapping estimation and event windows, i.e., firms that engaged in two different acts of misconduct that were very close together in time. For these cases, the first event was situated in the estimation window of the second event and, in line with standard practice in the event study literature, we dropped the second event from our sample (Engelen \& Kabir, 2006). In addition, we dropped ten events because the firms were not listed 
on a public stock market during the estimation window. Taken together, these actions reduced the sample to 423 acts of misconduct. When we collected the data for the control variables from Datastream, missing data further reduced the sample to 377. Finally, when we collected the data for board independence from corporate annual reports, additional missing data reduced the final sample to 345 .

\section{Measuring Cumulative Abnormal Returns}

Stock market reactions were measured as cumulative abnormal returns around the announcement of the misconduct using an event study approach (MacKinlay, 1997). This analytical approach examines whether the average abnormal returns (AAR) on the event day (announcement of the misconduct in the media) are equal to zero (null hypothesis) versus the alternative hypothesis of a non-zero average abnormal return. The average abnormal return on the event day $\left(\mathrm{AAR}_{\mathrm{E}}\right)$ is the aggregation of $N$ individual stock abnormal returns $\left(\mathrm{AR}_{\mathrm{i}, \mathrm{E}}\right)$ aligned in event time (MacKinlay, 1997):

$$
A A R_{E}=\frac{1}{N} \sum_{i=1}^{N} A R_{i, E}
$$

We examined the abnormal return pattern on the event day, and on two trading days before and after the reported misconduct, resulting in a 5-day event window $[-2,+2]$. As robustness checks, we also calculated abnormal returns over event windows $[-1,+1]$ and $[-1,0]$, where 0 indicates the event day, -1 the trading day before, and +1 the trading day after the event day (McWilliams \& Siegel, 1997). ${ }^{2}$ Abnormal stock returns $\left(\mathrm{AR}_{\mathrm{i}, \mathrm{t}}\right)$ were measured as the difference between the actual return on the event day $\left(\mathrm{R}_{\mathrm{i}, \mathrm{t}}\right)$ and the expected return $\mathrm{E}\left[\mathrm{R}_{\mathrm{i}, \mathrm{t}}\right]$, which what one would expect in the absence of the event or misconduct:

$$
A R_{i, t}=R_{i, t}-E\left[R_{i, t}\right]
$$

We used the market model to estimate the expected return on stock prices. ${ }^{3}$ In the market model, abnormal returns are calculated as $A R_{i, t}=R_{i, t}-\left(\hat{a}_{i}+\hat{b}_{i} \cdot R_{m, t}\right)$ , where ' $\wedge$ ' denotes the OLS-estimates from the market model $R_{i, t}=a_{i}+b_{i} \cdot R_{m, t}+e_{i, t}$ ' with $R_{i, t}$ the return of stock $i$ in period $t, R_{m, t}$ the market index return in period $t, a_{i}$ and $b_{i}$ the intercept and slope coefficient, respectively, of the market model (stock$i$-specific and time-independent parameters), and $e_{i, t}$ the random disturbance term of the market model for stock $i$ in period $t$. The parameters of the market model are estimated over a period from -130 to -11 trading days before the event day. The 120-day estimation period corresponds to calendar time period of half a year before the misconduct. Such an estimation period is typical in the event study literature (Engelen \& Kabir, 2006).

The significance of the mean abnormal returns is tested using the standard test statistic assuming cross-sectional independence (Brown \& Warner, 1985), which standardizes abnormal returns for each stock by its standard deviation $\left(\hat{s}_{i}\right)$ calculated from the estimation period: 


$$
t-\text { test }=\frac{\sum_{i=1}^{N} S A R_{i, E}}{\sqrt{N}} \sim t(N-1)
$$

with

$$
S A R_{i, E}=\frac{A R_{i, E}}{\hat{s}_{i}}
$$

\section{Explaining Cumulative Abnormal Returns}

Although the event study approach is one of the most commonly used methods in the finance literature (Kothari \& Warner, 2007), it does not allow researchers to examine the effects of different variables together in a multivariate framework. We therefore use standard OLS regression models to test our hypotheses, regressing our independent variables on cumulative abnormal stock returns (CARs) (Homburg, Vollmayr, \& Hahn, 2014; Paruchuri \& Misangyi, 2015). The regression approach provides a more robust framework for isolating the effects of specific variables than the bivariate, event study framework. In all regression models, we use robust standard errors, with observations clustered by firm because some firms in our sample were connected to more than one act of misconduct.

\section{Independent Variables}

Data for our independent variables were collected and coded from media coverage of the misconduct. Although we searched all media sources within each country to identify the acts of misconduct, to collect the data for our independent variables, we focused on a more narrow set of 20 general and business newspapers. For the UK, this included The Financial Times, The Times and The Independent; for the Netherlands: NRC Handelsblad, Het Financieele Dadblad, Algemeen Dagblad and De Volkskrant; for Belgium: De Tijd and L'Echo; for Germany: Börsen Zeitung, Handelsblatt, Allgemeine Zeitung, Berliner Zeitung, Die Zeit and Die Welt; and for France: Le Monde, Le Figaro, Les Echos, Le Journal des Finances, and La Tribune. We used these newspapers as proxies for all media coverage because they have the largest circulation in each country. We coded our independent variables using all articles published on the day that the media initially exposed each act of misconduct. We read and manually coded a total of 937 news articles with a total of 359,695 words. Stock price data, market return data, and other firm-level control variables were obtained from Thomson Reuters Datastream. Data on board independence was obtained from corporate annual reports. We now discuss how we measured and coded each independent variable in more detail.

\section{Media Coverage}

We measured media coverage as a continuous variable of the total number of words in the articles covering the misconduct. 


\section{Location of the Misconduct}

We collected information on the location of the misconduct (home market vs. foreign market) from the newspaper articles. We coded an event as "home market" if the media reported that the misconduct occurred in the country where the firm had its headquarters, and "foreign market" if the media reported that the misconduct occurred outside the country where the firm had its headquarters.

\section{Stage of the Social Construction Process}

We created a nominal variable with four categories to capture the stage at which the misconduct was reported, coding each event as "rumor," "formal investigation," "court proceeding," or "conviction/exoneration." When the media reported an allegation of misconduct, we coded the event as "rumor," such as a news story alleging that a firm supported a regime in a country violating human rights. We coded an event as "investigation" if the media first reported an act when it was under investigation by any organization with regulatory or enforcement authority at the local, regional, national, or continental levels. For example, an article reporting that the European Commission started a formal investigation into price-fixing on the French beer market was coded as "investigation." We coded an event as "court phase" if the media first reported misconduct when the firm or individuals were being tried in a court or another adjudicatory body. We coded an event as "outcome" if the media first reported the misconduct when it was in the stage at which the firm or individuals were being convicted or sanctions imposed by an administrative body, or at which the firm or individuals were found not guilty or exonerated. In the regression models, the category "outcome" is the reference category.

\section{Estimates of Impact}

We created a dichotomous variable coded as 1 if the media coverage included any estimates of fines, civil claims, magnitude of fraud, magnitude of bribe payments, damage payments, clean-up costs, or any other damages, and 0 otherwise. A total of 139 cases $(32.9 \%)$ of our sample had some estimate reported in the press, of which 99 reported a precise value (e.g., €34 million fine for market abuse) and 40 reported vague estimates (e.g., a multi-million dollar lawsuit). This percentage is similar to percentages found in previous studies (Karpoff \& Lott, 1993; Karpoff, Lott, \& Wehrly, 2005). When precise estimates were reported in the media, most figures were for potential fines (54 cases), civil claims (16 cases), and estimates of the magnitude of fraud (11 cases). There was significant heterogeneity in the estimates: some estimates were very precise, while others were very vague; some were imposed fines, while others were estimated fines; some were actual damage payments, while others were just claims with unclear credibility.

\section{Focus of Blame}

We created a nominal variable with four categories to measure how the media reported blame for the misconduct. When the media coverage explicitly blamed the corporation itself for the misconduct, we coded the variable as "corporation," such 
as a news story that reported that a firm bribed government officials of another country to win contracts. When an event's news coverage explicitly mentioned the name of the CEO, the CFO, or another member of the top management team, we coded this variable as "executives," such as an article about a police interrogation of the CEO of a firm suspected of bribery. When the article implicated employees who are not part of the top management team, we coded it as "employees." Finally, when the media coverage did not fit into any of these three categories, we coded the variables as "other." In the regression models, "other" is the reference category.

\section{Board Independence}

We calculated board independence as the percentage of directors who were independent in the year the misconduct was reported. A director was defined as independent if he or she was not an employee of the company (or its subsidiaries), had not been an employee in the past, did not have a family relationship with senior management, did not have a business relationship with the company (or its subsidiaries), and was not a major shareholder (Hooghiemstra \& Van Manen, 2004).

\section{Control Variables}

We collected data on additional variables to capture the potential impact of other factors on negative abnormal returns. The first was a measure of past misconduct by the firm. Since past misconduct is not new information to investors, the efficient market hypothesis would predict that it would not influence investor reactions to new misconduct. However, Lange and Washburn (2012) suggest that observers with existing negative beliefs about a company might be more likely to blame a company for new acts of misconduct than those by companies for which they had positive beliefs because existing beliefs often serve as an anchor for decision making (Tversky \& Kahneman, 1974). Other evidence suggests that investors might give firms without past misconduct the benefit of the doubt, with a more positive reputation serving as a buffer (Dorobantu et al., 2017; Janney \& Gove, 2011). To control for the possibility that past misconduct influenced investor reactions, we created a variable for each firm in our sample that counted the number of articles published during the five years before the event that included the firm's name and any of the aforementioned keywords relating to misconduct. We counted back five years starting from the day before the beginning of each event window.

In addition, we wanted to ensure that the volume of media coverage of the misconduct predicted to influence investor reactions in Hypothesis 1 was not capturing the effects of the general media coverage that firms receive. We therefore included a variable of nonnegative media coverage that was a continuous measure of the number of articles in our sample of newspapers that included the name of the firm during the five years before the misconduct was reported. We counted back five years starting from the day before the beginning of each event window. We subtracted from this total the number of articles that covered any previous misconduct in order to avoid collinearity issues with the variables measuring past misconduct. 
Since investors might be more concerned with different types of misconduct, e.g., financial fraud (Paruchuri \& Misangyi, 2015), we controlled for the type of misconduct. Using the newspaper articles, we classified each act using a ten-category typology: insider trading, corruption and bribery, accounting fraud, tax fraud, other fraud, price fixing (i.e., monopolistic practices), employee discrimination, human rights violations, environmental violations, and miscellaneous transgressions. To control for country, sector, and year effects, we used dummy variables for each country (5), each sector (19) and each year (11), with one of the countries, one of the sectors, and one of the years used as reference categories. We also controlled for standard predictors of stock market value. We measured firm age as the number of years since the founding of the company (Van Essen, Engelen, \& Carney, 2013), firm leverage as the value of debt divided by the value of total assets (Kedia \& Rajgopal, 2011), and the market-to-book ratio (Rajan \& Zingales, 1998). These data were obtained from Thomson Reuters Datastream. Table 1 provides descriptive statistics for all variables and Table 2 presents the correlation matrix for all variables.

\section{RESULTS}

The event study results revealed that companies that engage in misconduct experience an average stock price decline of $-1.41 \%$ in the five day period around the event day. A stock market penalty of about one and a half percent would mean that a company with a market capitalization of $€ 10$ billion euros lost $€ 150$ million in value. Since the overall sample is an aggregation of different misconduct events, however, a uniform interpretation of this penalty is challenging. Market reactions to different events are likely shaped by the factors we have hypothesized. Analyzing the events in a multivariate framework, therefore, permits a deeper examination. ${ }^{4}$

Table 3 presents the multivariate, OLS regression results with cumulative abnormal returns as the dependent variable. In Table 3, Model 1 is the baseline model with only control variables. Models $2-6$ show the controls with each independent variable on its own. Model 7 includes all the independent variables except for the interaction term of corporation blamed and independent board. Model 8 is the fully specified model, and we focus on the results presented in Model 8.

The results do not provide support for Hypothesis 1 that the volume of media coverage of misconduct is associated with negative investor reactions. The regression results do, however, support our core claim that investors react more negatively to information that enhances the clarity and credibility of the claims about misconduct. More specifically, the results provide support for Hypothesis 2 that investors react more negatively to misconduct that the media reports as occurring in their home market than in foreign markets $(\beta=-0.03, p<0.01)$. The results also provide support for Hypothesis 3 that formal investigations are negatively related to investor reactions $(\beta=-0.05, p<0.001)$. The results in Model 8 also reveal that investors react negatively to acts of misconduct that the media covers in the rumor stage $(\beta=-0.04, p<0.05)$. This variable, however, is insignificant in the other models, while the formal investigation variable is consistently significant across all models. In addition, the results show that investor reactions are more negative when the 
Table 1: Descriptive Statistics of Variables

\begin{tabular}{|c|c|c|c|c|c|}
\hline Variables & Observations & Mean & SD & Min & Max \\
\hline Number of Words & 423 & 850.30 & 929.80 & 0 & 5966 \\
\hline Home Market & 423 & 0.71 & 0.45 & 0 & 1 \\
\hline Foreign Market & 423 & 0.29 & 0.45 & 0 & 1 \\
\hline Rumor & 423 & 0.18 & 0.38 & 0 & 1 \\
\hline Investigation & 423 & 0.53 & 0.50 & 0 & 1 \\
\hline Court Phase & 423 & 0.10 & 0.31 & 0 & 1 \\
\hline Conviction & 423 & 0.20 & 0.40 & 0 & 1 \\
\hline Estimates of Any Impact & 423 & 0.33 & 0.47 & 0 & 1 \\
\hline Corporation Blamed & 423 & 0.66 & 0.47 & 0 & 1 \\
\hline Top Level Blamed & 423 & 0.19 & 0.39 & 0 & 1 \\
\hline Lower Level Blamed & 423 & 0.06 & 0.24 & 0 & 1 \\
\hline Unclear Blame & 423 & 0.09 & 0.28 & 0 & 1 \\
\hline Percentage of Independent Directors & 365 & 0.46 & 0.18 & 0 & 1 \\
\hline Number of Negative Articles & 423 & 3.00 & 6.00 & 0 & 106 \\
\hline Numbers of Nonnegative Articles & 423 & 312.20 & 418.50 & 0 & 2042 \\
\hline Accounting Fraud & 423 & 0.06 & 0.24 & 0 & 1 \\
\hline Tax Fraud & 423 & 0.04 & 0.19 & 0 & 1 \\
\hline Other Fraud & 423 & 0.16 & 0.37 & 0 & 1 \\
\hline Corruption \& Bribery & 423 & 0.06 & 0.24 & 0 & 1 \\
\hline Insider Trading & 423 & 0.18 & 0.39 & 0 & 1 \\
\hline Market Abuse & 423 & 0.23 & 0.42 & 0 & 1 \\
\hline Human Rights Violation & 423 & 0.08 & 0.27 & 0 & 1 \\
\hline Discrimination & 423 & 0.07 & 0.26 & 0 & 1 \\
\hline Environmental Violation & 423 & 0.09 & 0.29 & 0 & 1 \\
\hline Miscellaneous Misconduct & 423 & 0.03 & 0.17 & 0 & 1 \\
\hline Firm Age & 423 & 92.10 & 77.60 & 2 & 313 \\
\hline Book to Market Value & 390 & 2.60 & 3.87 & -0.51 & 34.71 \\
\hline Leverage & 398 & 0.26 & 0.17 & 0 & .93 \\
\hline Belgium & 423 & 0.08 & 0.28 & 0 & 1 \\
\hline France & 423 & 0.16 & 0.37 & 0 & 1 \\
\hline Germany & 423 & 0.31 & 0.46 & 0 & 1 \\
\hline Netherlands & 423 & 0.17 & 0.37 & 0 & 1 \\
\hline UK & 423 & 0.28 & 0.45 & 0 & 1 \\
\hline 1995 & 423 & 0.03 & 0.17 & 0 & 1 \\
\hline 1996 & 423 & 0.05 & 0.21 & 0 & 1 \\
\hline 1997 & 423 & 0.06 & 0.25 & 0 & 1 \\
\hline 1998 & 423 & 0.08 & 0.27 & 0 & 1 \\
\hline 1999 & 423 & 0.09 & 0.29 & 0 & 1 \\
\hline 2000 & 423 & 0.08 & 0.27 & 0 & 1 \\
\hline 2001 & 423 & 0.11 & 0.31 & 0 & 1 \\
\hline 2002 & 423 & 0.14 & 0.34 & 0 & 1 \\
\hline 2003 & 423 & 0.14 & 0.34 & 0 & 1 \\
\hline 2004 & 423 & 0.10 & 0.31 & 0 & 1 \\
\hline 2005 & 423 & 0.13 & 0.34 & 0 & 1 \\
\hline
\end{tabular}

Note. Years are dummy variables representaing the year in which the misconduct was reported. 
Table 2: Correlation Matrix

\begin{tabular}{|c|c|c|c|c|c|c|c|c|c|c|c|c|c|c|c|c|}
\hline & & 1 & 2 & 3 & 4 & 5 & 6 & 7 & 8 & 9 & 10 & 11 & 12 & 13 & 14 & 15 \\
\hline 1 & Media & - & & & & & & & & & & & & & & \\
\hline 2 & Home Country & 0.06 & - & & & & & & & & & & & & & \\
\hline 3 & Stage of Social Construction Process & 0.01 & 0.05 & - & & & & & & & & & & & & \\
\hline 4 & Any Impact Reported & 0.07 & $-0.19^{*}$ & $0.45^{*}$ & - & & & & & & & & & & & \\
\hline 5 & Focus of Blame & $-0.10^{*}$ & $-0.13^{*}$ & -0.02 & 0.00 & - & & & & & & & & & & \\
\hline 6 & Independent Board & $0.14^{*}$ & -0.08 & -0.04 & 0.00 & 0.01 & - & & & & & & & & & \\
\hline 7 & Past Media Coverage & $0.10^{*}$ & $-0.11^{*}$ & 0.04 & 0.01 & 0.01 & -0.01 & - & & & & & & & & \\
\hline 8 & Past Media Coverage of Misconduct & 0.07 & -0.06 & 0.00 & -0.01 & 0.02 & 0.10 & $0.50 *$ & - & & & & & & & \\
\hline 9 & Type of Misconduct & $-0.21 *$ & $-0.19^{*}$ & $0.15^{*}$ & 0.06 & $0.33 *$ & 0.03 & 0.07 & -0.04 & - & & & & & & \\
\hline 10 & Firm Age & $0.11 *$ & $-0.16^{*}$ & 0.09 & 0.08 & 0.01 & 0.03 & $0.20 *$ & $0.10^{*}$ & 0.09 & - & & & & & \\
\hline 11 & Book to Market Value & -0.01 & 0.03 & -0.02 & -0.04 & -0.09 & 0.06 & -0.04 & -0.02 & -0.02 & 0.00 & - & & & & \\
\hline 12 & Leverage & 0.01 & $0.12 *$ & 0.09 & 0.06 & $-0.16^{*}$ & 0.051 & -0.04 & 0.02 & -0.10 & -0.01 & 0.06 & - & & & \\
\hline 13 & Industry & 0.02 & $0.28 *$ & 0.08 & 0.00 & $-0.19 *$ & $-0.16^{*}$ & -0.00 & -0.03 & $-0.33^{*}$ & -0.03 & -0.07 & $0.13^{*}$ & - & & \\
\hline 14 & Year & 0.08 & $0.10^{*}$ & 0.08 & 0.07 & 0.03 & 0.04 & $0.19 *$ & 0.09 & 0.08 & -0.07 & -0.06 & 0.01 & 0.02 & - & \\
\hline 15 & Country & 0.09 & -0.01 & 0.07 & $0.12 *$ & $0.12 *$ & $0.45^{*}$ & 0.07 & $0.11^{*}$ & $0.16^{*}$ & 0.07 & 0.07 & -0.09 & $-0.14 *$ & 0.01 & - \\
\hline
\end{tabular}

Note. $\mathrm{N}=423 ; * p<.05$. 
Table 3: Results of OLS Models Predicting Cumulative Abnormal Returns

\begin{tabular}{|c|c|c|c|c|c|c|c|c|}
\hline & Model 1 & Model 2 & Model 3 & Model 4 & Model 5 & Model 6 & Model 7 & Model 8 \\
\hline Media - Number of Words & & $\begin{array}{l}-0.00 \\
(0.00)\end{array}$ & & & & & $\begin{array}{c}0.00 \\
(0.00)\end{array}$ & $\begin{array}{c}0.00 \\
(0.00)\end{array}$ \\
\hline Home Market & & & $\begin{array}{l}-0.03 * * \\
(0.01)\end{array}$ & & & & $\begin{array}{l}-0.03 * * \\
(0.01)\end{array}$ & $\begin{array}{l}-0.03 * * \\
(0.01)\end{array}$ \\
\hline Rumor & & & & $\begin{array}{l}-0.02 \\
(0.01)\end{array}$ & & & $\begin{array}{l}-0.03 \\
(0.01)\end{array}$ & $\begin{array}{l}-0.04 * \\
(0.02)\end{array}$ \\
\hline Investigation & & & & $\begin{array}{l}-0.03 * * \\
(0.01)\end{array}$ & & & $\begin{array}{l}-0.04^{* * * *} \\
(0.01)\end{array}$ & $\begin{array}{l}-0.05^{* * * *} * \\
(0.01)\end{array}$ \\
\hline Court Phase & & & & $\begin{array}{l}-0.01 \\
(0.02)\end{array}$ & & & $\begin{array}{l}-0.01 \\
(0.02)\end{array}$ & $\begin{array}{l}-0.02 \\
(0.02)\end{array}$ \\
\hline Any Impact Reported & & & & & $\begin{array}{c}0.00 \\
(0.01)\end{array}$ & & $\begin{array}{l}-0.02 * \\
(0.01)\end{array}$ & $\begin{array}{l}-0.03^{*} \\
(0.01)\end{array}$ \\
\hline Employees Blamed & & & & & & $\begin{array}{l}-0.02 \\
(0.02)\end{array}$ & $\begin{array}{l}-0.03 \\
(0.02)\end{array}$ & $\begin{array}{l}-0.07 \\
(0.05)\end{array}$ \\
\hline Executives Blamed & & & & & & $\begin{array}{l}-0.03 \\
(0.02)\end{array}$ & $\begin{array}{l}-0.03 \\
(0.03)\end{array}$ & $\begin{array}{l}-0.10 \\
(0.06)\end{array}$ \\
\hline Corporation & & & & & & $\begin{array}{l}-0.06^{*} \\
(0.03)\end{array}$ & $\begin{array}{l}-0.06^{*} \\
(0.03)\end{array}$ & $\begin{array}{l}-0.16^{* * *} \\
(0.05)\end{array}$ \\
\hline Independent Board (\%) & & & & & & & & $\begin{array}{l}-0.18 \\
(0.10)\end{array}$ \\
\hline Independent Board * Executives & & & & & & & & $\begin{array}{c}0.09 \\
(0.13)\end{array}$ \\
\hline Independent Board * Employees & & & & & & & & $\begin{array}{c}0.18 \\
(0.12)\end{array}$ \\
\hline Independent Board * Corporation & & & & & & & & $\begin{array}{c}0.22^{*} \\
(0.09)\end{array}$ \\
\hline Past Media Coverage & $\begin{array}{c}0.00 \\
(0.00)\end{array}$ & $\begin{array}{c}0.00 \\
(0.00)\end{array}$ & $\begin{array}{c}0.00 \\
(0.00)\end{array}$ & $\begin{array}{c}0.00 \\
(0.00)\end{array}$ & $\begin{array}{c}0.00 \\
(0.00)\end{array}$ & $\begin{array}{c}0.00 \\
(0.00)\end{array}$ & $\begin{array}{c}0.00 \\
(0.00)\end{array}$ & $\begin{array}{c}0.00 \\
(0.00)\end{array}$ \\
\hline Past Media Coverage - Misconduct & $\begin{array}{c}0.00^{*} \\
(0.00)\end{array}$ & $\begin{array}{c}0.00 * \\
(0.00)\end{array}$ & $\begin{array}{c}0.00 * \\
(0.00)\end{array}$ & $\begin{array}{c}0.00 * \\
(0.00)\end{array}$ & $\begin{array}{c}0.00^{*} \\
(0.00)\end{array}$ & $\begin{array}{c}0.00^{*} \\
(0.00)\end{array}$ & $\begin{array}{c}0.00 * \\
(0.00)\end{array}$ & $\begin{array}{c}0.00 \\
(0.00)\end{array}$ \\
\hline
\end{tabular}


Table 3: continued

\begin{tabular}{|c|c|c|c|c|c|c|c|c|}
\hline & Model 1 & Model 2 & Model 3 & Model 4 & Model 5 & Model 6 & Model 7 & Model 8 \\
\hline Accounting Fraud & $\begin{array}{l}-0.09 * * \\
(0.03)\end{array}$ & $\begin{array}{l}-0.09 * \\
(0.03)\end{array}$ & $\begin{array}{l}-0.09 * * \\
(0.03)\end{array}$ & $\begin{array}{l}-0.08^{*} \\
(0.03)\end{array}$ & $\begin{array}{l}-0.09 * * \\
(0.03)\end{array}$ & $\begin{array}{l}-0.11 * * \\
(0.04)\end{array}$ & $\begin{array}{l}-0.09 * \\
(0.04)\end{array}$ & $\begin{array}{l}-0.10^{*} \\
(0.04)\end{array}$ \\
\hline Tax Fraud & $\begin{array}{l}-0.00 \\
(0.02)\end{array}$ & $\begin{array}{l}-0.00 \\
(0.02)\end{array}$ & $\begin{array}{l}-0.01 \\
(0.02)\end{array}$ & $\begin{array}{c}0.01 \\
(0.02)\end{array}$ & $\begin{array}{l}-0.00 \\
(0.02)\end{array}$ & $\begin{array}{l}-0.02 \\
(0.02)\end{array}$ & $\begin{array}{l}-0.02 \\
(0.03)\end{array}$ & $\begin{array}{l}-0.02 \\
(0.03)\end{array}$ \\
\hline Other Fraud & $\begin{array}{l}-0.03 \\
(0.02)\end{array}$ & $\begin{array}{l}-0.02 \\
(0.02)\end{array}$ & $\begin{array}{l}-0.03 \\
(0.02)\end{array}$ & $\begin{array}{l}-0.02 \\
(0.02)\end{array}$ & $\begin{array}{l}-0.03 \\
(0.02)\end{array}$ & $\begin{array}{l}-0.04 \\
(0.02)\end{array}$ & $\begin{array}{l}-0.03 \\
(0.02)\end{array}$ & $\begin{array}{l}-0.03 \\
(0.02)\end{array}$ \\
\hline Corruption & $\begin{array}{l}-0.03 \\
(0.02)\end{array}$ & $\begin{array}{l}-0.02 \\
(0.02)\end{array}$ & $\begin{array}{l}-0.04 \\
(0.02)\end{array}$ & $\begin{array}{l}-0.02 \\
(0.02)\end{array}$ & $\begin{array}{l}-0.03 \\
(0.02)\end{array}$ & $\begin{array}{l}-0.03 \\
(0.02)\end{array}$ & $\begin{array}{l}-0.04 \\
(0.02)\end{array}$ & $\begin{array}{l}-0.04 \\
(0.02)\end{array}$ \\
\hline Insider Trading & $\begin{array}{l}-0.02 \\
(0.02)\end{array}$ & $\begin{array}{l}-0.02 \\
(0.02)\end{array}$ & $\begin{array}{l}-0.01 \\
(0.02)\end{array}$ & $\begin{array}{l}-0.01 \\
(0.02)\end{array}$ & $\begin{array}{l}-0.02 \\
(0.02)\end{array}$ & $\begin{array}{l}-0.06^{*} \\
(0.03)\end{array}$ & $\begin{array}{l}-0.05 \\
(0.03)\end{array}$ & $\begin{array}{l}-0.06 \\
(0.03)\end{array}$ \\
\hline Market Abuse & $\begin{array}{l}-0.03 \\
(0.02)\end{array}$ & $\begin{array}{l}-0.03 \\
(0.02)\end{array}$ & $\begin{array}{l}-0.03 \\
(0.02)\end{array}$ & $\begin{array}{l}-0.03 \\
(0.02)\end{array}$ & $\begin{array}{l}-0.03 \\
(0.02)\end{array}$ & $\begin{array}{l}-0.03 \\
(0.02)\end{array}$ & $\begin{array}{l}-0.02 \\
(0.02)\end{array}$ & $\begin{array}{l}-0.03 \\
(0.02)\end{array}$ \\
\hline Human Rights & $\begin{array}{l}-0.02 \\
(0.02)\end{array}$ & $\begin{array}{l}-0.02 \\
(0.02)\end{array}$ & $\begin{array}{l}-0.04 * \\
(0.02)\end{array}$ & $\begin{array}{l}-0.02 \\
(0.02)\end{array}$ & $\begin{array}{l}-0.02 \\
(0.02)\end{array}$ & $\begin{array}{l}-0.02 \\
(0.02)\end{array}$ & $\begin{array}{l}-0.04 \\
(0.02)\end{array}$ & $\begin{array}{l}-0.04 \\
(0.02)\end{array}$ \\
\hline Discrimination & $\begin{array}{l}-0.02 \\
(0.02)\end{array}$ & $\begin{array}{l}-0.02 \\
(0.02)\end{array}$ & $\begin{array}{l}-0.02 \\
(0.02)\end{array}$ & $\begin{array}{l}-0.02 \\
(0.02)\end{array}$ & $\begin{array}{l}-0.02 \\
(0.02)\end{array}$ & $\begin{array}{l}-0.02 \\
(0.02)\end{array}$ & $\begin{array}{l}-0.02 \\
(0.02)\end{array}$ & $\begin{array}{l}-0.03 \\
(0.02)\end{array}$ \\
\hline Environment & $\begin{array}{l}-0.01 \\
(0.02)\end{array}$ & $\begin{array}{l}-0.01 \\
(0.02)\end{array}$ & $\begin{array}{l}-0.02 \\
(0.02)\end{array}$ & $\begin{array}{l}-0.01 \\
(0.02)\end{array}$ & $\begin{array}{l}-0.01 \\
(0.02)\end{array}$ & $\begin{array}{l}-0.01 \\
(0.02)\end{array}$ & $\begin{array}{l}-0.02 \\
(0.02)\end{array}$ & $\begin{array}{l}-0.02 \\
(0.02)\end{array}$ \\
\hline Firm Age & $\begin{array}{c}0.00 \\
(0.00)\end{array}$ & $\begin{array}{c}0.00 \\
(0.00)\end{array}$ & $\begin{array}{c}0.00 \\
(0.00)\end{array}$ & $\begin{array}{c}0.00 \\
(0.00)\end{array}$ & $\begin{array}{c}0.00 \\
(0.00)\end{array}$ & $\begin{array}{c}0.00 \\
(0.00)\end{array}$ & $\begin{array}{c}0.00 \\
(0.00)\end{array}$ & $\begin{array}{c}0.00 \\
(0.00)\end{array}$ \\
\hline Book to Market Value & $\begin{array}{l}0.00 \text { *** } \\
(0.00)\end{array}$ & $\begin{array}{l}0.00 \text { **** } \\
(0.00)\end{array}$ & $\begin{array}{l}0.00 * * * \\
(0.00)\end{array}$ & $\begin{array}{l}0.00 * * * \\
(0.00)\end{array}$ & $\begin{array}{l}0.00 * * * \\
(0.00)\end{array}$ & $\begin{array}{l}0.00 * * * \\
(0.00)\end{array}$ & $\begin{array}{l}0.00 * * * \\
(0.00)\end{array}$ & $\begin{array}{l}0.00 * * * \\
(0.00)\end{array}$ \\
\hline Leverage & $\begin{array}{c}0.04 \\
(0.04)\end{array}$ & $\begin{array}{c}0.04 \\
(0.04)\end{array}$ & $\begin{array}{c}0.05 \\
(0.04)\end{array}$ & $\begin{array}{c}0.04 \\
(0.04)\end{array}$ & $\begin{array}{c}0.04 \\
(0.04)\end{array}$ & $\begin{array}{c}0.04 \\
(0.04)\end{array}$ & $\begin{array}{c}0.05 \\
(0.04)\end{array}$ & $\begin{array}{c}0.06 \\
(0.04)\end{array}$ \\
\hline Constant & $\begin{array}{c}0.03 \\
(0.03)\end{array}$ & $\begin{array}{c}0.03 \\
(0.03)\end{array}$ & $\begin{array}{c}0.06 \\
(0.03)\end{array}$ & $\begin{array}{c}0.05 \\
(0.03)\end{array}$ & $\begin{array}{c}0.03 \\
(0.03)\end{array}$ & $\begin{array}{c}0.08^{*} \\
(0.04)\end{array}$ & $\begin{array}{c}0.15^{* *} \\
(0.05) 0\end{array}$ & $\begin{array}{l}0.24 * * * \\
(0.07)\end{array}$ \\
\hline Number of Events & 377 & 377 & 377 & 377 & 377 & 377 & 377 & 345 \\
\hline R-squared & 0.19 & 0.19 & 0.21 & 0.21 & 0.19 & 0.24 & 0.25 & 0.27 \\
\hline
\end{tabular}

Note. Models include controls for firm age, industry, year, and country. Table reports unstandardized coefficients and robust standard errors in parentheses, clustered by company. $* p<0.05$,

$* * p<0.01$, *** $p<0.001$. 
media reports some estimate of the misconduct's impact $(\beta=-0.03, p<0.05)$, thus providing support for Hypothesis 4.

Turning to focus of blame and restorative capacity, the results provide support for Hypothesis 5 that investors react more negatively when the corporation is blamed $(\beta=-0.16, p<0.01)$. The coefficients for executives blamed and employees blamed are not statistically significant. To test Hypothesis 6 that the effect of the corporation being blamed is positively moderated by the level of board independence, Model 8 includes the interaction term between these two variables. The interaction effect is positive $(\beta=0.22, p<0.05)$, providing support for Hypothesis 6: when the corporation is blamed but the firm has stronger governance in place, investor reactions are less negative. To more precisely assess when stronger governance is important, we identified the Johnson-Neyman point (Spiller, Fitzsimons, Lynch Jr, \& McClelland, 2013) in the distribution of the values of the board independence variable, which is the point at which a moderating effect becomes significant. ${ }^{5}$ More specifically, we conducted a series of "spotlight" analyses described by Spiller et al. (2013) and found that the Johnson-Neyman point occurs when the percentage of independent board members is between $40 \%$ and $41 \%$. This means that the relationship between the corporation being blamed and negative abnormal stock returns is statistically significant when the percentage of independent directors is below $40 \%$ and not significant when the percentage of independent directors is above $41 \%$. In other words, as the percentage of independent directors gets close to and exceeds a majority, investors are less likely to react negatively to the misconduct when the corporation is blamed.

In terms of controls, we found few significant effects. The coefficient for past negative media coverage is not statistically significant, and although past nonnegative media coverage is significant $(p<.05)$, the coefficient is zero. In terms of types of misconduct, accounting fraud is associated with the largest negative investor reactions. This makes sense because such acts raise a fundamental question for investors about the soundness of the firm's financial position.

Finally, we conducted two robustness checks. First, we examined the impact of outliers by winsorizing the dependent variable at three standard deviations from the mean and reran our regression models (Herbohn \& Ragunathan, 2008; Johnston \& Madura, 2009; Marquardt \& Wiedman, 2004). The results are almost identical to the original regression results, demonstrating that outliers are likely not having a disproportionate effect on our outcomes. Second, we ran regressions using a different measure of the dependent variable, market-adjusted abnormal returns, and found very similar results. ${ }^{6}$

\section{DISCUSSION}

This article developed a framework for explaining variation in investor reactions to unethical corporate behavior. Our approach takes a social constructionist view of misconduct, in which corporate behavior that can potentially be categorized as misconduct only becomes such when market actors reach shared agreement about these assessments. We focus on one key part of the social construction process: how the media shapes the initial assessments of investors. Our results provide support for our core claim that the 
content of the information reported by the media has an important influence on investor reactions. More specifically, we found evidence of negative abnormal stock returns when the media reported information that enhances the clarity and credibility of the claims that it was misconduct that occurred and that the firm was responsible for it. This information appears to enhance the overall clarity of the signal sent by the media, reducing both the ambiguity about the misconduct and the heterogeneity of investor responses to it. We also found that investors reacted more negatively when information in the media blamed the corporation rather than specific individuals, and that this relationship was positively moderated by the level of board independence. This suggests that for investors, the depth of ethical problems and the firm's ability to fix it also provide important signals about the likelihood that the firm will incur reputational penalties.

Our results, however, also showed that when acts of misconduct were exposed in the rumor stage, investors reacted more negatively. This suggests that the clarity and credibility of information may not be the only important factor driving investor reactions. Other research, for example, has found that for any act of misconduct, investor reactions are often the largest at the time of its initial exposure (Agguzoni et al., 2013; Muoghalu et al., 1990). Although investigations likely provide a clearer signal than rumors that the misconduct occurred and that the firm is responsible, when an act is exposed during the rumor stage, investor reactions may be driven less by the clarity of the claims and more by the initial exposure of any information. These two mechanisms are not mutually exclusive, and examining the influence of the media and the information they report through all stages of the social control process is an important avenue for future research.

In addition, although previous research has found that the volume of media coverage influences investor reactions to IPOs and earnings announcements (Bushee et al., 2010; Pollock \& Rindova, 2003), our findings suggest that the volume of coverage does not influence investor reactions in a consistent enough way across enough investors to influence abnormal returns. It is important to note, however, that we focused on a set number of high-circulation newspapers on the first day that the misconduct was reported. Although these were likely representative of overall coverage, we may not have captured the effects of events that received high volumes of coverage outside these high circulation outlets or after the date of initial media exposure.

As a whole, however, our findings demonstrate the key role that the media play in shaping investor reactions to misconduct. Existing research has provided evidence that investors react negatively to corporate misconduct, but has moved little beyond the core insight that variation in these reactions depends on whether the effected stakeholders have a direct exchange relationship with the firm (Karpoff, 2012). Our evidence extends this literature, as well as the broader literature in management (Bednar, 2012), finance (Tetlock, 2007), and accounting (Dai et al., 2015) that has examined the corporate governance role of the media. For this literature, our findings reveal how signals sent by a third party like the media influence investor perceptions in situations where corporations are motivated to maintain information asymmetry. In addition, although previous work has found that ambiguous signals about the quality of corporate performance leads investors to undervalue firms (Park \& Patel, 2015), in the case of misconduct we find that ambiguity leads them to inaction. 
More broadly, our analysis demonstrates the importance of building deeper connections between business ethics scholarship and specific strands of the management, accounting, and finance literatures. Although the business ethics literature has examined the role of the media in promoting ethical behavior (Dickson \& Eckman, 2008; El Ghoul et al., 2016; Grafström \& Windell, 2011), drawing upon these other literatures allowed us to theorize how the media can also shape perceptions of and reactions to unethical behavior. By reducing information asymmetry that often benefits corporations, the media can enhance the market's efficiency in punishing and deterring misconduct. This insight is especially important considering recent research that has demonstrated the market's inefficiency in punishing misconduct (Wesley \& Ndofor, 2015). Our findings, however, do not allow us to assess the extent to which shareholders and the media actually deter future unethical behavior. Gaining deeper insight into whether these two key non-state actors function as effective deterrents is an important avenue for future research. Although the media can reduce information asymmetry, since they make choices about what to cover and how to cover it based on their own strategic business concerns, as well as the priorities and preferences of individual editors and journalists (Rindova, Pollock, \& Hayward, 2006), coverage may lack objectivity and not cover all acts of misconduct equally. On a practical level, however, our findings may help the media to better understand their role in informing investors and motivate them to cover unethical corporate behavior more objectively and aggressively.

\section{Implications for Management Practice}

Our findings also reveal that managers need to pay careful attention to any media coverage of their firm's behavior that can be categorized as misconduct, especially if this coverage provides clear and credible claims about the behavior. Managers should be prepared for the negative investors reactions that are likely to follow such coverage, and perhaps more importantly, prepared to engage in restorative actions and demonstrate restorative capacity. Since we find that investors react negatively even to rumors of misconduct, it is also important for managers to begin restorative efforts as early as possible to get out ahead of rumors. Moreover, just as the media plays an important role in publicizing misconduct, the media can play a role in helping firms in their reintegration and restorative efforts after misconduct has been exposed (Gillespie \& Dietz, 2009; Pfarrer et al., 2008; Zavyalova et al., 2012). More specifically, the effectiveness of efforts at restoration and reintegration depend on firms engaging in a range of both verbal responses and substantive actions, and these efforts often unfold in specific stages (Bertels et al., 2015; Gillespie et al., 2014). By broadcasting these efforts through the media, deviant firms can help to mitigate investor concerns about reputational damage and the recurrence of misconduct in the future.

Our findings also suggest that board independence mitigates negative investor reactions when the media assign blame to the corporation rather than specific individuals. As the percentage of independent directors gets close to and exceeds a majority, investors appear more likely to expect that the firm has sufficient restorative capacity to address the systemic organizational causes of the misconduct. This suggests that firms can help to protect themselves against negative investor reactions by develop- 
ing their restorative capacity, including by increasing the percentage of independent board members. Other ways to develop restorative capacity might include building internal knowledge of legitimacy restoration through training, improving monitoring and auditing systems, and strengthening stakeholder engagement practices. Our findings regarding the importance of board independence also suggest that the common approach of scapegoating and firing executives after misconduct is exposed (Connelly et al., 2016) may not be the most effective restorative strategy, particularly when the corporation itself is blamed in the initial media coverage.

\section{Implications for Public Policy}

By reducing information asymmetry, the media can improve the market's efficiency in punishing misconduct, and to the extent that the stock market is efficient in punishing misconduct, regulation may be less necessary or redundant (Karpoff, 2012). For example, since investors react more negatively to acts relating to primary stakeholders, some have argued that laws are more important for deterring misconduct relating to secondary stakeholders, such as environmental violations (Alexander, 1999; Karpoff et al., 2008; Karpoff \& Lott, 1993). However, as Barnett (2014: 678) has observed, market-based mechanisms will only be effective deterrents "to the degree that stakeholders present a credible threat of punishing those firms that engage in misconduct." Our analysis suggests that the media help to foment such threats. This role should be recognized by legislators, regulators, and enforcement agencies, and potentially used to inform new policy-making and enforcement efforts. For example, if investors do not react negatively to an act of misconduct because it is not reported in the media or because of the ambiguity of the information reported, stronger regulations or new enforcement mechanisms may be required.

\section{Market Reactions to Misconduct Across the World}

In the broader context of globalization, our analysis is the first to examine investor reactions to misconduct in a cross-national, European sample. Some scholars have argued that Europe has a weaker regulatory system relating to corporate misconduct (Enriques \& Volpin, 2007), and that public reactions to corporate scandals are weaker because governments in Europe are less likely to let firms fail (Coffee, 2005) and ownership structures are more concentrated than in the US (Enriques \& Volpin, 2007). We find, however, that European investors, similar to those in the US, react negatively to corporate misconduct, suggesting that they may be motivated by different concerns than the general public and that stock markets may be serving a deterrent function. Examining the cross-regional differences in investor reactions between Europe, North America, Asia, and other parts of the world, and the role of the media in shaping these reactions in different national settings, represents a key area for future research. Such studies would provide much needed insight into how national-level culture and institutions shape reactions to similar types of misconduct and could productively engage with work that has demonstrated how such factors shape the incidence of misconduct (Bame-Aldred et al., 2013; Martin et al., 2007). Moreover, understanding the media's role in reducing or exacerbating information 
asymmetry is especially important in emergent economies such as China, where the state exerts a more significant influence over the media than in Western Europe.

\section{Limitations}

Like all empirical research, our analysis has important limitations. First, our dataset ended in 2005, about the time that the media landscape began to experience a significant change with the rise of social media including Twitter and Facebook. Social media has fundamentally altered the dynamics of communication between corporations, the news media, and stakeholders (Hewett, Rand, Rust, \& van Heerde, 2016), and accelerated the speed at which some news stories go viral. Although these changes may have important and novel implications for how investors react to corporate misconduct, an emerging literature in journalism and communication studies has provided substantial evidence that the most popular social media platforms, including Facebook and Twitter, most often share links to media articles and drive reader traffic to traditional news content (An, Cha, Gummadi, \& Crowcroft, 2011; Kwak, Lee, Park, \& Moon, 2010; Lasorsa, Lewis, \& Holton, 2012; Newman, 2009, 2011; Smith \& Lee, 2010). In other words, social media usually refers users to the same content that has been the focus of our inquiry. This suggests that investor reactions to misconduct in the age of social media will be shaped by similar dynamics as what we have found in our analysis. However, the amplification of media coverage of specific acts of corporate misconduct by social media might also function as a signal to investors of the responsiveness of stakeholders to these acts, which may provide additional information to investors and influence their reactions independently of the effects we have found here for the content of coverage. A key avenue for future research, therefore, is to assess the extent to which the social media amplify, dampen, or otherwise alter the effects of the content about the misconduct in the media.

Another limitation of our analysis is that we were unable to obtain standardized cross-country data on corporate reputation in the European context. Other research has found that a firm's existing reputation for corporate social responsibility can either exacerbate or mitigate investor reactions to misconduct (Flammer, 2012; Janney \& Gove, 2011), depending on the specific issue on which a firm's reputation rests. It is important, therefore, for future research to develop ways to measure reputation outside of the US context. In fact, going back to the example discussed at the beginning of this article, one possible explanation for why Volkswagen experienced a more substantial stock market penalty than GM is that since Volkswagen had a reputation as a progressive and ethical company, particularly relating to environmental issues (Preston, 2015), the market reacted more strongly when the firm violated these expectations. Since GM did not have the same reputation, its unethical behavior may not have been that surprising to investors and other stakeholders.

\section{CONCLUSION}

Gaining a deeper understanding of the complex relationships between the media, shareholders, and the state, and how they promote ethical corporate behavior and 
deter unethical behavior has become more critical as stock markets become more important societal arbiters of ethical behavior and our understanding of the cognitive limits faced by investors deepens (Barberis \& Thaler, 2003). Furthermore, as markets become more interconnected globally and the ability of nation-states to regulate the behavior of firms weakens (Scherer et al., 2009), understanding variation in investor reactions across different national contexts is essential. We hope that the framework we have developed here and our findings in support of it will motivate new research to advance these debates and inform new policy alternatives and management approaches.

\section{ACKNOWLEDGEMENTS}

The article has benefited greatly from feedback provided by Yasmin Kor, Elizabeth Maitland, Donald Palmer, and participants in the Organizations and Social Change Research Seminar at the University of Massachusetts Boston. We also thank associate editor Kelly Martin and two anonymous reviewers for their very helpful developmental feedback.

\section{NOTES}

1. We thank an anonymous reviewer for highlighting the importance of reducing variation in investor interpretations.

2. Results are largely the same and do not alter our conclusions. Results from all supplemental analyses are available from the authors upon request.

3. The market model is one of the most commonly used in event studies (McWilliams \& Siegel, 1997). We did not include the results from other models (e.g., market-adjusted) because prior research has shown that results are largely independent of model selection (Engelen \& Kabir, 2006). We did, however, run the regression models using market-adjusted model, and the results were unchanged. Results are available from the authors.

4. The bivariate event study results with median split analyses for different subsamples are available from the authors upon request.

5. We thank an anonymous reviewer for suggesting this analysis.

6. The results from these auxiliary analyses are available from the authors upon request.

\section{REFERENCES}

Agguzoni, L., Langus, G., \& Motta, M. 2013. The effect of EU antitrust investigations and fines on a firm's valuation. Journal of Industrial Economics, 61(2): 290-338.

Aguilera, R. V., Desender, K., Bednar, M. K., \& Lee, J. H. 2015. Connecting the dots: Bringing external corporate governance into the corporate governance puzzle. The Academy of Management Annals, 9(1): 483-573.

Ahmad, K., Han, J., Hutson, E., Kearney, C., \& Liu, S. 2016. Media-expressed negative tone and firm-level stock returns. Journal of Corporate Finance, 37: 152-172.

Alexander, C. R. 1999. On the nature of the reputational penalty for corporate crime: Evidence. Journal of Law and Economics, 42(S1): 489-526.

An, J., Cha, M., Gummadi, K., \& Crowcroft, J. 2011. Media landscape in Twitter: A world of new conventions and political diversity. Paper presented at the Fifth International AAAI Conference on Weblogs and Social Media.

Ashforth, B. E., \& Gibbs, B. W. 1990. The double-edge of organizational legitimation. Organization Science, 1(2): 177-194. 
Bame-Aldred, C. W., Cullen, J. B., Martin, K. D., \& Parboteeah, K. P. 2013. National culture and firm-level tax evasion. Journal of Business Research, 66(3): 390-396.

Bansal, P., \& Clelland, I. 2004. Talking trash: Legitimacy, impression management, and unsystematic risk in the context of the natural environment. Academy of Management Journal, 47(1): 93-103.

Barberis, N., \& Thaler, R. 2003. A survey of behavioral finance. Handbook of the Economics of Finance, 1: 1053-1128.

Barnett, M. L. 2014. Why stakeholders ignore firm misconduct: A cognitive view. Journal of Management, 40(3): 676-702.

Bednar, M. K. 2012. Watchdog or lapdog? A behavioral view of the media as a corporate governance mechanism. Academy of Management Journal, 55(1): 131-150.

Bednar, M. K., Boivie, S., \& Prince, N. R. 2013. Burr under the saddle: How media coverage influences strategic change. Organization Science, 24(3): 910-925.

Bergh, D. D., \& Gibbons, P. 2011. The stock market reaction to the hiring of management consultants: A signalling theory approach. Journal of Management Studies, 48(3): 544-567.

Berscheid, E., Graziano, W., Monson, T., \& Dermer, M. 1976. Outcome dependency: Attention, attribution, and attraction. Journal of Personality and Social Psychology, 34(5): 978.

Bertels, S., Cody, M., \& Pek, S. 2015. A responsive approach to organizational misconduct: Rehabilitation, reintegration, and the reduction of reoffense. Business Ethics Quarterly, 24(3): 343-370.

Breit, E. 2009. On the (re)construction of corruption in the media: A critical discursive approach. Journal of Business Ethics, 92(4): 619-635.

Brown, J. A., Buchholtz, A. K., \& Dunn, P. 2016. Moral salience and the role of goodwill in firm-stakeholder trust repair. Business Ethics Quarterly, 26(02): 181-199.

Brown, M. E., \& Treviño, L. K. 2006. Ethical leadership: A review and future directions. The Leadership Quarterly, 17(6): 595-616.

Brown, S. J., \& Warner, J. B. 1985. Using daily stock returns: The case of event studies. Journal of Financial Economics, 14(1): 3-31.

Bundy, J., Shropshire, C., \& Buchholtz, A. K. 2013. Strategic cognition and issue salience: Toward an explanation of firm responsiveness to stakeholder concerns. Academy of Management Review, 38(3): 352-376.

Bushee, B. J., Core, J. E., Guay, W., \& Hamm, S. J. W. 2010. The role of the business press as an information intermediary. Journal of Accounting Research, 48(1): $1-19$.

Carberry, E. J., \& King, B. G. 2012. Defensive practice adoption in the face of organizational stigma: Impression management and the diffusion of stock option expensing. Journal of Management Studies, 49(7): 1137-1167.

Carroll, C. E., \& McCombs, M. 2003. Agenda-setting effects of business news on the public's images and opinions about major corporations. Corporate Reputation Review, 6(1): $36-46$.

Certo, S. T. 2003. Influencing initial public offering investors with prestige: Signaling with board structures. Academy of Management Review, 28(3): 432-446.

Christensen, T. E., Paik, D. G. H., \& Williams, C. D. 2010. Market efficiency and investor reactions to sec fraud investigations. Journal of Forensic \& Investigative Accounting, 2(3): 1-30. 
Coffee, J. C. 2005. A theory of corporate scandals: Why the USA and Europe differ. Oxford Review of Economic Policy, 21(2): 198-211.

Connelly, B. L., Ketchen, D. J., Gangloff, K. A., \& Shook, C. L. 2016. Investor perceptions of CEO successor selection in the wake of integrity and competence failures: A policy capturing study. Strategic Management Journal, 37: 2135-2151.

Core, J. E., Guay, W., \& Larcker, D. F. 2008. The power of the pen and executive compensation. Journal of Financial Economics, 88(1): 1-25.

Dai, L., Parwada, J. T., \& Zhang, B. 2015. The governance effect of the media's news dissemination role: Evidence from insider trading. Journal of Accounting Research, 53(2): 331-366.

Davidson, W. N., \& Worrel, D. L. 1988. The impact of announcements of corporate illegalities on shareholder returns. Academy of Management Journal, 31(1): 195-200.

Deephouse, D. L., \& Heugens, P. P. M. A. R. 2008. Linking social issues to organizational impact: The role of infomediaries and the infomediary process. Journal of Business Ethics, 86(4): 541-553.

Desai, V. M. 2011. Mass media and massive failures: Determining organizational efforts to defend field legitimacy following crises. Academy of Management Journal, 54(2): 263-278.

Devers, C. E., Dewett, T., Mishina, Y., \& Belsito, C. 2009. A general theory of organizational stigma. Organization Science, 20(1): 154-171.

Dickson, M. A., \& Eckman, M. 2008. Media portrayal of voluntary public reporting about corporate social responsibility performance: Does coverage encourage or discourage ethical management? Journal of Business Ethics, 83(4): 725-743.

Doh, J. P., Howton, S. D., Howton, S. W., \& Siegel, D. S. 2009. Does the market respond to an endorsement of social responsibility? The role of institutions, information, and legitimacy. Journal of Management, 36(6): 1461-1485.

Dorobantu, S., Henisz, W. J., \& Nartey, L. 2017. Not all sparks light a fire: Stakeholder and shareholder reactions to critical events in contested markets. Administrative Science Quarterly, 62: 561-597.

El Ghoul, S., Guedhami, O., Nash, R., \& Patel, A. 2016. New evidence on the role of the media in corporate social responsibility. Journal of Business Ethics. DOI: 10.1007/ s10551-016-3354-9.

Engelen, P. J., \& Kabir, R. 2006. Empirical evidence on the role of trading suspensions in disseminating new information to the capital market. Journal of Business Finance \& Accounting, 33(7-8): 1142-1167.

Engelen, P. J., \& van Essen, M. 2011. Reputational penalites in financial markets: An ethical mechanism? In W. Vandekerckhove, J. Leys, K. Alm, B. Scholtens, S. Signori, \& H. Schafer (Eds.), Responsible investment in times of turmoil: 55-74. New York: Springer Publishers.

Enriques, L., \& Volpin, P. 2007. Corporate governance reforms in continental Europe. The Journal of Economic Perspectives, 21(1): 117-140.

Epstein, L. G., \& Schneider, M. 2008. Ambiguity, information quality, and asset pricing. The Journal of Finance, 63(1): 197-228.

Fang, L., \& Peress, J. 2009. Media coverage and the cross-section of stock returns. The Journal of Finance, 64(5): 2023-2052.

Felps, W., Mitchell, T. R., \& Byington, E. 2006. How, when, and why bad apples spoil the barrel: Negative group members and dysfunctional groups. Research in Organizational Behavior, 27: 175-222. 
Fiss, P. C., \& Zajac, E. J. 2004. The diffusion of ideas over contested terrain: The (non) adoption of a shareholder value orientation among german firms. Administrative Science Quarterly, 49(4): 501-534.

Flammer, C. 2012. Corporate social responsibility and shareholder reaction: The environmental awareness of investors. Academy of Management Journal, 56(3): 758-781.

Frooman, J. 1997. Socially irresponsible and illegal behavior and shareholder wealth: A meta-analysis of event studies. Business \& Society, 36(3): 221-249.

Fukushima, K. 2014. GM stock falls amid ignition switch recall investigation. The Street, http://www.thestreet.com/story/12948081/1/general-motors-gm-stock-falls-amidignition-switch-recall-investigation.html.

Gillespie, N., \& Dietz, G. 2009. Trust repair after an organization-level failure. Academy of Management Review, 34(1): 127-145.

Gillespie, N., Dietz, G., \& Lockey, S. 2014. Organizational reintegration and trust repair after an integrity violation: A case study. Business Ethics Quarterly, 24(3): 371-410.

Goodstein, J., \& Butterfield, K. D. 2010. Extending the horizon of business ethics: Restorative justice and the aftermath of unethical behavior. Business Ethics Quarterly, 20(3): 453-480.

Goodstein, J., Butterfield, K. D., Pfarrer, M. D., \& Wicks, A. C. 2014. Guest editors' introduction: Individual and organizational reintegration after ethical or legal transgressions: Challenges and opportunities. Business Ethics Quarterly, 24(3): 315-342.

Grafström, M., \& Windell, K. 2011. The role of infomediaries: CSR in the business press during 2000-2009. Journal of Business Ethics, 103(2): 221-237.

Greve, H. R., Palmer, D., \& Pozner, J. E. 2010. Organizations gone wild: The causes, processes, and consequences of organizational misconduct. Academy of Management Annals, 4(1): 53-107.

Hamilton, V. L. 1980. Intuitive psychologist or intuitive lawyer? Alternative models of the attribution process. Journal of Personality and Social Psychology, 39(5): 767.

Herbohn, K., \& Ragunathan, V. 2008. Auditor reporting and earnings management: Some additional evidence. Accounting \& Finance, 48(4): 575-601.

Hewett, K., Rand, W., Rust, R. T., \& van Heerde, H. J. 2016. Brand buzz in the echoverse. Journal of Marketing, 80(3): 1-24.

Hirsh, C. E., \& Cha, Y. 2015. Employment discrimination lawsuits and corporate stock prices. Social Currents, 2(1): 40-57.

Hirshleifer, D., \& Teoh, S. H. 2003. Limited attention, information disclosure, and financial reporting. Journal of Accounting and Economics, 36(1-3): 337-386.

Homburg, C., Vollmayr, J., \& Hahn, A. 2014. Firm value creation through major channel expansions: Evidence from an event study in the United States, Germany, and China. Journal of Marketing, 78(3): 38-61.

Hooghiemstra, R., \& Van Manen, J. 2004. The independence paradox: (Im)possibilities facing nonexecutive directors in the Netherlands. Corporate Governance: An International Review, 12(3): 314-324.

Huberman, G. 2001. Familiarity breeds investment. Review of Financial Studies, 14(3): 659-680.

Huizinga, H., \& Nicodème, G. 2006. Foreign ownership and corporate income taxation: An empirical evaluation. European Economic Review, 50(5): 1223-1244.

Ivory, D. 2014. G.M.'s ignition problem: Who knew what when. New York Times, September 15. https://www.nytimes.com/interactive/2014/05/18/business/gmsignition-problem-who-knew-what-when.html. 
Janney, J. J., \& Gove, S. 2011. Reputation and corporate social responsibility aberrations, trends, and hypocrisy: Reactions to firm choices in the stock option backdating scandal. Journal of Management Studies, 48(7): 1562-1585.

Johnston, J., \& Madura, J. 2009. The pricing of IPOs post-Sarbanes-Oxley. Financial Review, 44(2): 291-310.

Jonsson, S., \& Buhr, H. 2011. The limits of media effects: Field positions and cultural change in a mutual fund market. Organization Science, 22(2): 464-481.

Kahneman, D., \& Tversky, A. 1979. Prospect theory: An analysis of decision under risk. Econometrica, 47(2): 263-292.

Karpoff, J. M. 2012. Does reputation work to discipline corporate misconduct? In T. G. Pollock \& M. L. Barnett (Eds.), Oxford handbook of corporate reputation: 361-382. Oxford: Oxford University Press.

Karpoff, J. M., Lee, D. S., \& Martin, G. S. 2008. The cost to firms of cooking the books. Journal of Financial and Quantitative Analysis, 43(03): 581-581.

Karpoff, J. M., \& Lott, J. 1993. Reputational penalty firms bear from committing criminal fraud. Journal of Law and Economics, 36: 757-802.

Karpoff, J. M., Lott, J., \& Wehrly, E. W. 2005. The reputational penalties for environmental violations: Empirical evidence. Journal of Law and Economics, 48(2): 653-675.

Kedia, S., \& Rajgopal, S. (2011). Do the SEC's enforcement preferences affect corporate misconduct? Journal of Accounting and Economics, 51(3): 259-278.

King, B. G., \& Soule, S. 2007. Social movements as extra-institutional entrepreneurs: The effect of protests on stock price returns. Administrative Science Quarterly, 52: 413-422.

Kothari, S., \& Warner, J. 2007. Econometrics of event studies. In B. E. Eckbo (Ed.), Handbook of corporate finance, volume 1. North-Holland: Elsevier.

Kwak, H., Lee, C., Park, H., \& Moon, S. 2010. What is Twitter, a social network or a news media? Proceedings of the 19th International Conference on World Wide Web.

La Monica, P. R. 2015. Volkswagen has plunged 50\%. Will it ever recover? CNNMoney, September 25. http://money.cnn.com/2015/09/24/investing/volkswagen-vw-emissionsscandal-stock/.

Lange, D., \& Washburn, N. T. 2012. Understanding attributions of corporate social irresponsibility. Academy of Management Review, 37(2): 300-326.

Lasorsa, D. L., Lewis, S. C., \& Holton, A. E. 2012. Normalizing Twitter: Journalism practice in an emerging communication space. Journalism Studies, 13(1): 19-36.

Lee, S. Y., \& Riffe, D. 2017. Who sets the corporate social responsibility agenda in the news media? Unveiling the agenda-building process of corporations and a monitoring group. Public Relations Review, 43(2): 293-305.

Luckerson, V. 2015. GM near settlement with us over ingition-switch scandal, Fortune, September 17. http://fortune.com/2015/09/17/gm-ignition-switch-settlement/.

MacKinlay, A. C. 1997. Event studies in economics and finance. Journal of Economic Literature: $13-39$.

March, J. G. 1978. Bounded rationality, ambiguity, and the engineering of choice. The Bell Journal of Economics: 587-608.

Marquardt, C. A., \& Wiedman, C. I. 2004. The effect of earnings management on the value relevance of accounting information. Journal of Business Finance \& Accounting, 31(4): 297-332.

Martin, K. D., \& Cullen, J. B. 2006. Continuities and extensions of ethical climate theory: A meta-analytic review. Journal of Business Ethics, 69(2): 175-194. 
Martin, K. D., Cullen, J. B., Johnson, J. L., \& Parboteeah, K. P. 2007. Deciding to bribe: A cross-level analysis of firm and home country influences on bribery activity. Academy of Management Journal, 50(6): 1401-1422.

Martin, K. D., Johnson, J. L., \& Cullen, J. B. 2009. Organizational change, normative control deinstitutionalization, and corruption. Business Ethics Quarterly, 19(1): $105-130$.

McCombs, M. 2005. A look at agenda-setting: Past, present and future. Journalism Studies, 6(4): 543-557.

McCombs, M. E., \& Shaw, D. L. 1972. The agenda-setting function of mass media. Public Opinion Quarterly, 36(2): 176-187.

McWilliams, A., \& Siegel, D. 1997. Event studies in management research: Theoretical and empirical issues. Academy of Management Journal, 40(3): 626-657.

Miller, G. S. 2006. The press as a watchdog for accounting fraud. Journal of Accounting Research, 44(5): 1001-1033.

Mishina, Y., Block, E. S., \& Mannor, M. J. 2012. The path dependence of organizational reputation: How social judgment influences assessments of capability and character. Strategic Management Journal, 33(5): 459-477.

Muoghalu, M. I., Robison, H. D., \& Glascock, J. L. 1990. Hazardous waste lawsuits, stockholder returns, and deterrence. Southern Economic Journal, 57(2): 357.

Newman, N. 2009. The rise of social media and its impact on mainstream journalism. Reuters Institute for the Study of Journalism, University of Oxford. . 2011. Mainstream media and the distribution of news in the age of social discovery. Reuters Institute for the Study of Journalism, University of Oxford.

Palmer, D. 2012. Normal organizational wrongdoing: A critical analysis of theories of misconduct in and by organizations. Oxford: Oxford University Press.

Palmer, D., \& Yenkey, C. B. 2015. Drugs, sweat, and gears: An organizational analysis of performance-enhancing drug use in the 2010 tour de france. Social Forces, 94(2): 891-922.

Park, H. D., \& Patel, P. C. 2015. How does ambiguity influence IPO underpricing? The role of the signalling environment. Journal of Management Studies, 52(6): 796-818.

Paruchuri, S., \& Misangyi, V. F. 2015. Investor perceptions of financial misconduct: The heterogeneous contamination of bystander firms. Academy of Management Journal, 58(1): 169-194.

Pfarrer, M. D., Decelles, K. A., Smith, K. G., \& Taylor, M. S. 2008. After the fall: Reintegrating the corrupt organization. Academy of Management Review, 33(3): 730-749.

Pollock, T. G., \& Rindova, V. P. 2003. Media legitimation effects in the market for initial public offerings. Academy of Management Journal, 46(5): 631-642.

Preston, B. 2015. Volkswagen scandal tarnishes hard-won us reputation as green company. The Guardian, September 25. https://www.theguardian.com/business/2015/sep/25/ volkswagen-scandal-us-reputation-emissions.

Rajan, R. G., \& Zingales, L. 1998. Financial dependence and growth. American Economic Review, 88: 559-586.

Rhee, E. Y., \& Fiss, P. C. 2014. Framing controversial actions: Regulatory focus, source credibility, and stock market reaction to poison pill adoption. Academy of Management Journal, 57(6): 1734-1758.

Rindova, V. P., Pollock, T. G., \& Hayward, M. L. A. 2006. Celebrity firms: The social construction of market popularity Academy of Management Journal, 31(1): 50-71. 
Scherer, A. G., Palazzo, G., \& Baumann, D. 2006. Global rules and private actors: Toward a new role of the transnational corporation in global governance. Business Ethics Quarterly, 16(4): 505-532.

Scherer, A. G., Palazzo, G., \& Matten, D. 2009. Introduction to the special issue: Globalization as a challenge for business responsibilities. Business Ethics Quarterly, 19(3): 327-347.

Shadnam, M., \& Lawrence, T. B. 2011. Understanding widespread misconduct in organizations. Business Ethics Quarterly, 21(3): 379-407.

Smith, A., \& Lee, R. 2010. 8\% of online americans use Twitter. Pew Research Center, December 9. http://pewinternet.org/Reports/2010/Twitter-update-2010.aspx.

Spence, M. 1973. Job market signalling. Quarterly Journal of Economics, 87(3): 355-374.

-2002. Signaling in retrospect and the informational structure of markets. American Economic Review, 92(3): 434-459.

Spiller, S. A., Fitzsimons, G. J., Lynch Jr, J. G., \& McClelland, G. H. 2013. Spotlights, floodlights, and the magic number zero: Simple effects tests in moderated regression. Journal of Marketing Research, 50(2): 277-288.

Stout, L. A. 2012. The shareholder value myth: How putting shareholders first harms investors, corporations, and the public. San Francisco: Berrett-Koehler Publishers.

Suchman, M. C. 1995. Managing legitimacy: Strategic and institutional approaches. Academy of Management Review, 20(3): 571-610.

Tetlock, P. C. 2007. Giving content to investor sentiment: The role of media in the stock market. The Journal of Finance, 62(3): 1139-1168.

Treviño, L. K., Weaver, G. R., \& Reynolds, S. J. 2006. Behavioral ethics in organizations: A review. Journal of Management, 32(6): 951-990.

Tversky, A., \& Kahneman, D. 1974. Judgment under uncertainty: Heuristics and biases. Science, 185(4157): 1124-1131.

Van Essen, M., Engelen, P. J., \& Carney, M. 2013. Does "good” corporate governance help in a crisis? The impact of country and firm level governance mechanisms in the European financial crisis. Corporate Governance: An International Review, 21(3): 201-224.

Vaughan, D. 1997. The Challenger launch decision: Risky technology, culture, and deviance at NASA. Chicago: University of Chicago Press.

Waldron, T. L., Navis, C., \& Fisher, G. 2013. Explaining differences in firms' responses to activism. Academy of Management Review, 38(3): 397-417.

Wesley, C. L., \& Ndofor, H. A. 2015. The great escape: The unaddressed ethical issue of investor responsibility for corporate malfeasance. Business Ethics Quarterly, 23(3): 443-475.

Zavyalova, A., Pfarrer, M. D., Reger, R. K., \& Shapiro, D. L. 2012. Managing the message: The effects of firm actions and industry spillovers on media coverage following wrongdoing. Academy of Management Journal, 55(5): 1079-1101.

Zhang, Y., \& Wiersema, M. F. 2009. Stock market reaction to CEO certification: The signaling role of CEO background. Strategic Management Journal, 30(7): 693-710. 